\title{
LARGE IGNEOUS PROVINCES AND KIMBERLITES? ORIGIN OF THE DIAMONDIFEROUS AMON KIMBERLITES, BAFFIN ISLAND, ARCTIC CANADA
}

\author{
S. Tappe ${ }^{1}$, G.M. Nowell ${ }^{2}$, S. Kurszlaukis ${ }^{3}$, and B.A. Kjarsgaard ${ }^{4}$ \\ ${ }^{I}$ Department of Earth and Atmospheric Sciences, University of Alberta, Edmonton, Canada \\ ${ }^{2}$ Department of Earth Sciences, Durham University, Durham, United Kingdom \\ ${ }^{3}$ De Beers Canada Inc., Toronto, Canada \\ ${ }^{4}$ Geological Survey of Canada, Ottawa, Canada
}

\section{INTRODUCTION}

Although kimberlite magmatic events produce only insignificant volumes of magma, it is increasingly recognized that kimberlite magmatism can be temporally and spatially associated with large outpourings of continental flood basalts (Ernst and Bleeker, 2010; Rao and Lehmann, 2011). Examples of kimberlites forming part of Large Igneous Provinces (LIPs) include the Siberian Trap event in Russia (e.g., Carlson et al., 2006) and the Deccan event in India (Lehmann et al., 2010), but the potential genetic relationships between these contrasting types of magmatism remain unclear. While this does not appear to be surprising given the ambiguity that surrounds the genetic origins of both kimberlite and flood basalt magmas (i.e., upper versus lower mantle derivation), a conceptual framework that helps to explain this possible connection may ultimately serve as a guide to the origin of kimberlites. In this contribution we discuss geochronology and compositional data of the diamondiferous Amon kimberlites in north-central Baffin Island, for which an apparent temporal and spatial relationship exists with the middle Neoproterozoic Franklin LIP in the Canadian Arctic (Fig.1).

\section{GEOLOGY OF THE AMON KIMBERLITES}

The Amon kimberlites in north-central Baffin Island were discovered by De Beers Canada during drilling in 2005, and further delineated during a second drilling program in 2006. Several thin hypabyssal kimberlite sheets were found to intrude granitic gneisses, which form part of the Late Archean basement of the Rae structural province of the Churchill craton (Hoffman, 1988).

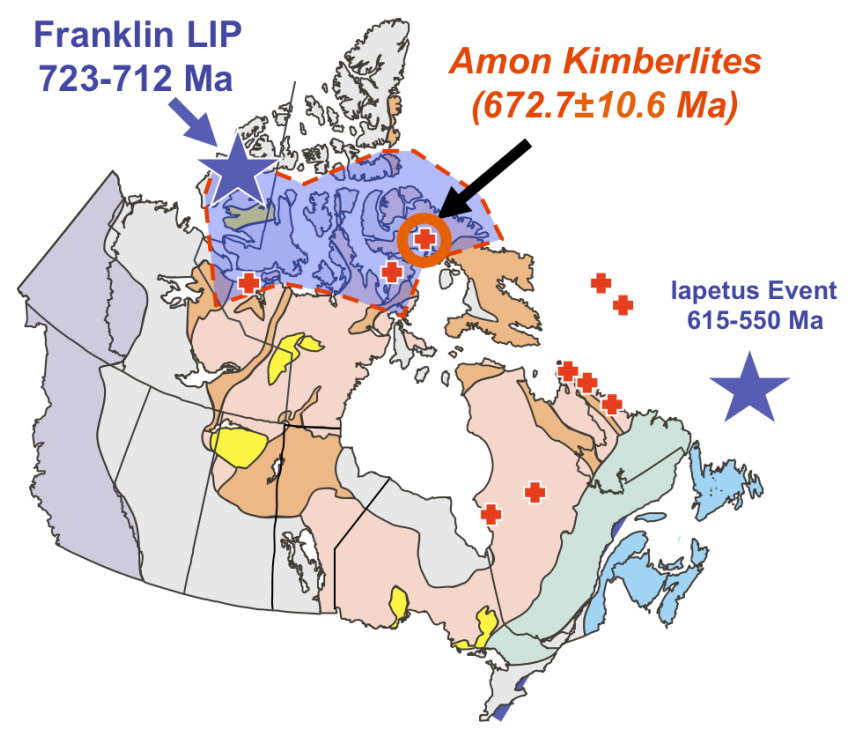

Figure 1: Geological map of Canada showing the location of the Amon kimberlites in northern Baffin Island. Also shown is the area that was impacted by Franklin igneous events (dashed outline). Red crosses are occurrences of Neoproterozoic kimberlites and related rocks in Canada and Greenland.

The maximum thickness of the kimberlite sheets does not exceed one meter and they appear to form a nearly horizontal sill complex $\left(<25^{\circ}\right.$ northward dip $)$. The kimberlite sheets typically show evidence for multiple injections of magma, with fine-grained aphanitic kimberlite comprising the chilled margins ( $<5 \%$ olivine macrocrysts) and macrocrystic varieties occupying the interior portions ( $>20 \%$ macrocrysts). Observed flow alignment of prismatic minerals points to the possibility that some of the kimberlite melt moved by filter pressing due to a decrease in magma pressure. Common macrocryst phases are olivine, pyrope- 


\section{$10^{\text {th }}$ International Kimberlite Conference, Bangalore - 2012}

rich garnet, and picro-ilmenite rarely exceeding $10 \mathrm{~mm}$ in the longest dimension. Olivine is the most abundant phenocryst phase and typically forms up to $2 \mathrm{~mm}$ long euhedral prisms. The olivine is completely replaced by carbonate and serpentine. The kimberlite groundmass consists of phlogopite, spinel, ilmenite, and apatite microphenocrysts $(<100 \mathrm{um})$ in a matrix of calcite, with rare serpentine plus quartz. Rutile is a common primary groundmass phase and has also been found replacing ilmenite and possibly perovskite. Rutile furthermore forms overgrowths on ilmenite macrocrysts and groundmass spinels. Monticellite and clinopyroxene are conspicuously absent in the Amon kimberlites.

\section{AGE OF THE AMON KIMBERLITES}

Two translucent orange-to-yellow rutile fractions from a kimberlite sheet were analysed by conventional ID-TIMS (Fig.2). These multi-grain fractions yielded indistinguishable ${ }^{206} \mathrm{~Pb} /{ }^{238} \mathrm{U}$ ages of $673.5 \pm 15.0 \mathrm{Ma}$ and $671.9 \pm 15.4 \mathrm{Ma}$, which allowed calculation of a weighted average age of $672.7 \pm 10.6 \mathrm{Ma}$ (2-sigma). Based on textural observations and mineral compositional data, we interpret the analysed rutile as a primary groundmass phase and the determined $\mathrm{U}-\mathrm{Pb}$ age of $\sim 673 \pm 11 \mathrm{Ma}$ is considered here the currently best estimate of kimberlite magma emplacement in north-central Baffin Island. This $\mathrm{U}-\mathrm{Pb}$ rutile age is in good agreement with the ${ }^{40} \mathrm{Ar} /{ }^{39} \mathrm{Ar}$ groundmass phlogopite age of $662 \pm 13 \mathrm{Ma}$ (2-sigma), which was determined for a piece of kimberlite float from the same area at an early exploration stage. It thus appears that the Amon kimberlite sill complex is only marginally younger than the 723-712 Ma 'giant' Franklin mafic dyke swarm that runs across northern Baffin Island in northwest-trending direction (Pehrsson and Buchan, 1999; Denyszyn et al., 2009).

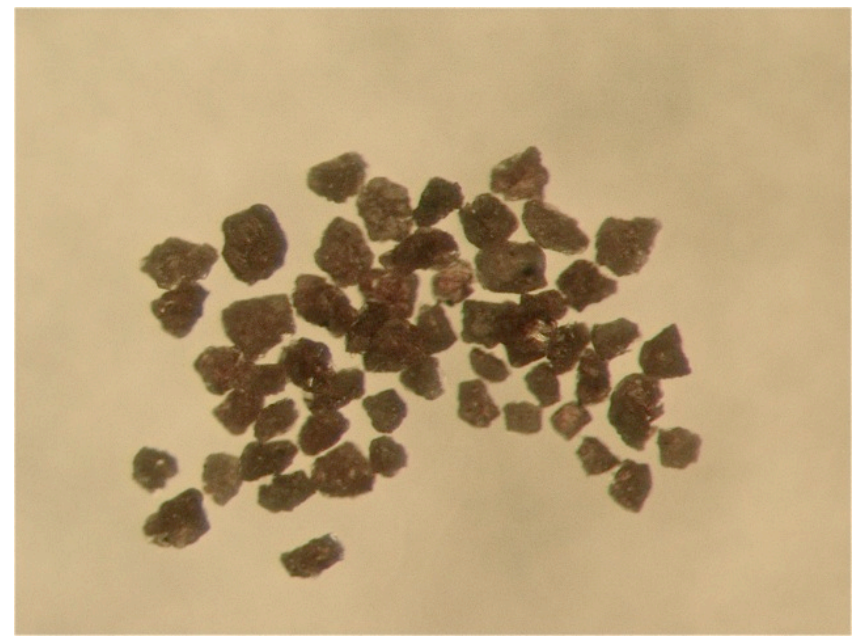

Figure 2: Multi-grain groundmass rutile fraction from a kimberlite sheet of the Amon sill complex as used for U-Pb age determinations. Field of view is $\sim 1.3 \mathrm{~mm}$.

\section{KIMBERLITE COMPOSITION}

\section{Mineralogy}

Groundmass phlogopite compositions of the Amon kimberlites show strong $\mathrm{Al}_{2} \mathrm{O}_{3}$ - and $\mathrm{BaO}$-enrichment (up to 20 and $9 \mathrm{wt} \%$, respectively), and $\mathrm{TiO}_{2}$-depletion (down to $0.4 \mathrm{wt} \%$ ) toward the rims (Fig.3). This feature is characteristic for archetypal kimberlites worldwide, but it appears to be absent from the kimberlitic rocks of the neighbouring Greenland-Labrador Diamond Province (Tappe et al., 2008; Nielsen et al., 2009). Furthermore, the Amon kimberlite phlogopites have core compositions that are characterized by relatively low $\mathrm{TiO}_{2}(0.4-4.0 \mathrm{wt} \%)$ and elevated $\mathrm{Cr}_{2} \mathrm{O}_{3}$ contents (up to $1.6 \mathrm{wt} \%$ ). The $\mathrm{F}$ content $(0.2-1.0 \mathrm{wt} \%)$ of the groundmass phlogopite is also slightly elevated.

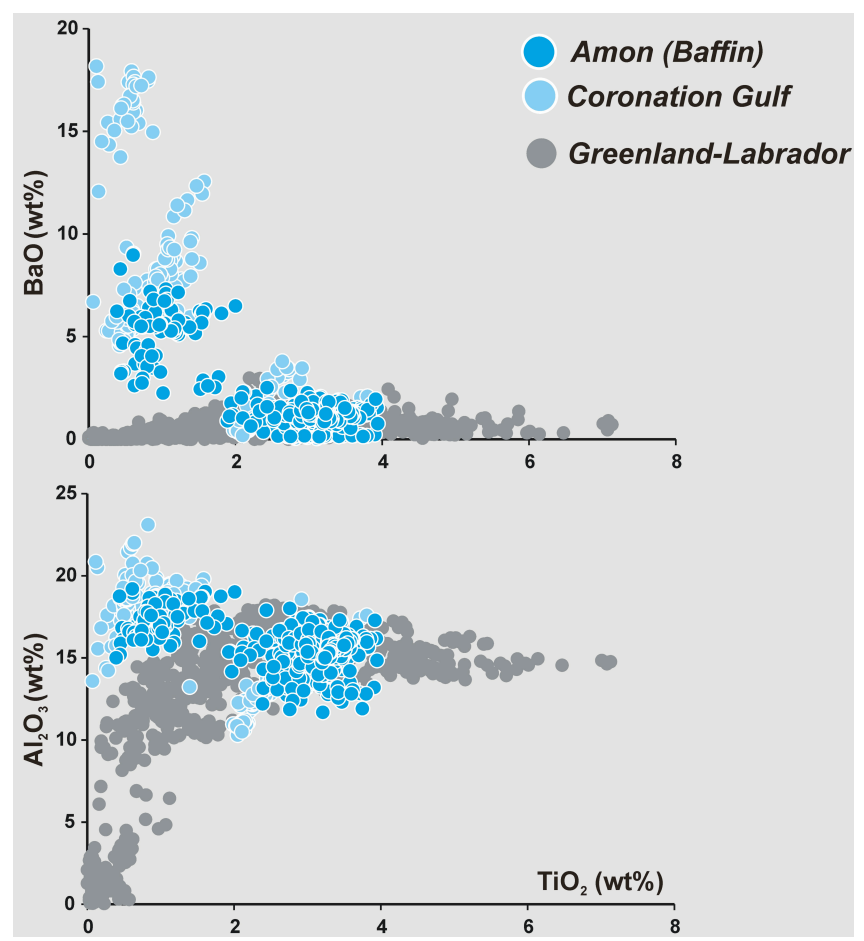

Figure 3: $\mathrm{BaO}$ and $\mathrm{Al}_{2} \mathrm{O}_{3}$ vs. $\mathrm{TiO}_{2}$ for groundmass phlogopite from the Amon kimberlites. Phlogopite compositions from the Neoproterozoic Coronation Gulf kimberlites (Armstrong et al., this volume) and Greenland-Labrador aillikites (Tappe et al., 2008; Nielsen et al., 2009) are shown for comparison.

Groundmass spinel comprises Cr-rich varieties and almost pure magnetite end-member compositions, the latter of which are not further considered here. The Cr-spinel grains are $\mathrm{MgO}$-rich (up to $15 \mathrm{wt} \%$ ) and resemble spinel compositions from worldwide Group-I kimberlites. However, Amon kimberlite spinels display a rather restricted coverage of the evolutionary spectrum typically shown by kimberlitic spinels. They fall in between the "magnesio ulvöspinel" and "titanomagnetite" trends when 


\section{$10^{\text {th }}$ International Kimberlite Conference, Bangalore - 2012}

projected onto the front face of the reduced spinel prism, and this feature has been previously described from carbonate-rich kimberlitic dykes of the neighbouring Greenland-Labrador Diamond Province (Tappe et al., 2009; Nielsen et al., 2009). Ilmenite laths in the kimberlite matrix contain between 13 and $19 \mathrm{wt} \% \mathrm{MgO}$. Their $\mathrm{Cr}_{2} \mathrm{O}_{3}$ and $\mathrm{MnO}$ concentration levels are elevated between 0.7-4.3 and $0.5-2.3 \mathrm{wt} \%$, respectively, which is typical of kimberlitic groundmass ilmenite.

The quite abundant rutile in the groundmass of the Amon kimberlites may have slightly elevated $\mathrm{FeO}$ and $\mathrm{MnO}$ contents (up to 4 and $1.4 \mathrm{wt} \%$, respectively). The $\mathrm{Cr}_{2} \mathrm{O}_{3}$ concentration levels are typically below $0.5 \mathrm{wt} \%$, except for the rutile rims on ilmenite macrocrysts, where $\mathrm{Cr}_{2} \mathrm{O}_{3}$ approaches $1.5 \mathrm{wt} \%$. Rutile is typically much more stable than perovskite in $\mathrm{CO}_{2}$-rich systems (Mitchell and Chakhmouradian, 1998), which explains its predominance over and reaction relationship with other titanates in the very carbonate-rich Amon kimberlites. The primary groundmass rutile described here is compositionally similar to rutile from the Benfontein calcite kimberlite sill in South Africa (Boctor and Boyd, 1981). Interestingly, groundmass rutile appears to be absent from orangeites (formerly Group-II kimberlites; Mitchell, 1995).

\section{Geochemistry}

The Amon kimberlites have high $\mathrm{MgO}$ (15-33 wt\%), Ni (294-1130 ppm), and $\mathrm{Cr}$ (710-1610 ppm) contents. They are relatively poor in $\mathrm{SiO}_{2}(13-33 \mathrm{wt} \%)$, $\mathrm{TiO}_{2}(1.9-3.5 \mathrm{wt} \%)$, $\mathrm{Al}_{2} \mathrm{O}_{3}(1.7-4.0 \mathrm{wt} \%), \mathrm{K}_{2} \mathrm{O}(0.1-1.4 \mathrm{wt} \%)$, and $\mathrm{Na}_{2} \mathrm{O}(0.02-$ $0.17 \mathrm{wt} \%$ ), resembling archetypal Group-I kimberlites from southern Africa (e.g., Le Roex et al., 2003). However, we note the elevated $\mathrm{CO}_{2}$ contents of the Amon kimberlites (625 wt\%; Fig.4), which fall at the upper end of the hypabyssal Group-I kimberlite spectrum, with the Lac de Gras kimberlites of the Slave craton as a prime example (Kjarsgaard et al., 2009).

The primitive mantle normalized incompatible element abundance patterns in Figure 5 demonstrate the strong trace element enrichment of the Amon kimberlites. Ba, Th, $\mathrm{U}$, $\mathrm{Nb}$, Ta, and LREE concentrations typically exceed 100 times primitive mantle. Pronounced relative depletions are apparent for $\mathrm{Cs}-\mathrm{Rb}, \mathrm{K}, \mathrm{Pb}, \mathrm{Sr}, \mathrm{Zr}-\mathrm{Hf}$, and the HREE, for which concentrations drop to below 5 times primitive mantle. Although much more enriched in highly incompatible elements than OIBs, the Amon kimberlites show $\mathrm{Ce} / \mathrm{Pb}(36 \pm 24)$ and $\mathrm{Nb} / \mathrm{U}(24 \pm 19)$ ratios that are more similar to plume-related intraplate oceanic magmas $(\mathrm{Ce} / \mathrm{Pb}$ $=25 \pm 5 ; \mathrm{Nb} / \mathrm{U}=47 \pm 10)$ than to subduction-influenced mafic alkaline magmas such as orogenic lamproites $(\mathrm{Ce} / \mathrm{Pb}$ and $\mathrm{Nb} / \mathrm{U}<10$ ).

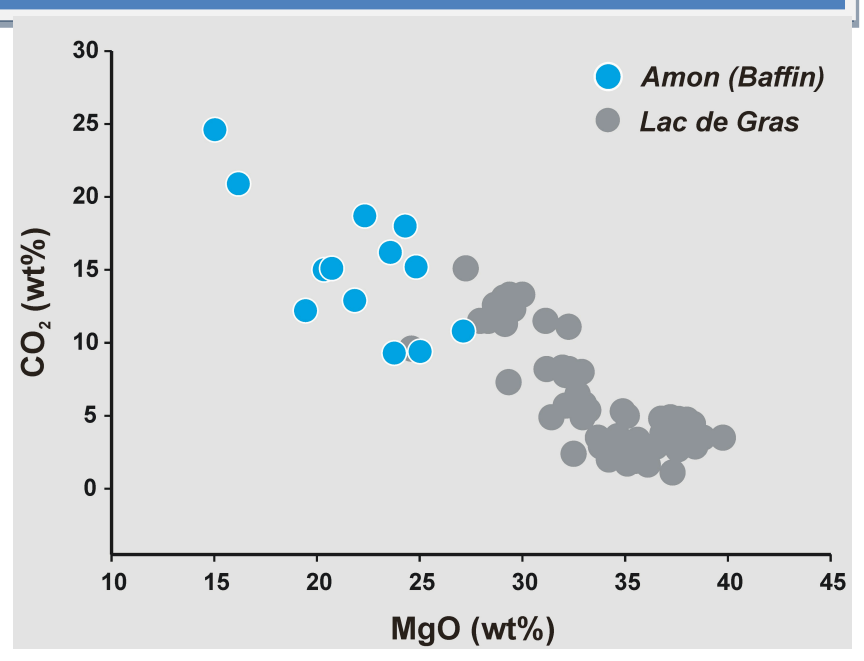

Figure 4: $\mathrm{CO}_{2}$ vs. $\mathrm{MgO}$ for bulk kimberlite samples from the Amon sill complex. Hypabyssal Lac de Gras (Slave craton) kimberlite compositions are shown for comparison (Kjarsgaard et al., 2009; and unpublished).

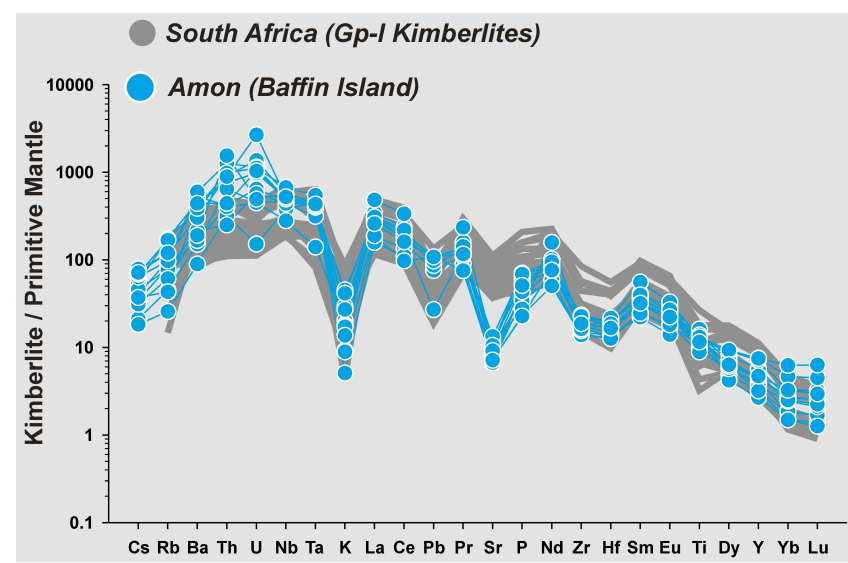

Figure 5: Normalized incompatible element diagram for Amon kimberlites. Hypabyssal Group-I kimberlites from South Africa are shown for comparison (Le Roex et al., 2003).

\section{Nd-Hf isotope systematics}

The Amon kimberlites have moderately depleted Nd-Hf isotope systematics (epsilon $\mathrm{Ndi}=+0.5$ to +3.4 ; epsilon $\mathrm{Hfi}$ $=-1.1$ to +8.1$)$ and define an array in $\mathrm{Nd}-\mathrm{Hf}$ isotope space that is nearly perpendicular to the terrestrial array (Fig.6). Such a trend is highly unusual for mantle-derived magmas given the typically strong coupling of the Sm-Nd and Lu-Hf isotope systems in the Bulk Silicate Earth (Blichert-Toft and Albarede, 1997). 


\section{$10^{\text {th }}$ International Kimberlite Conference, Bangalore - 2012}

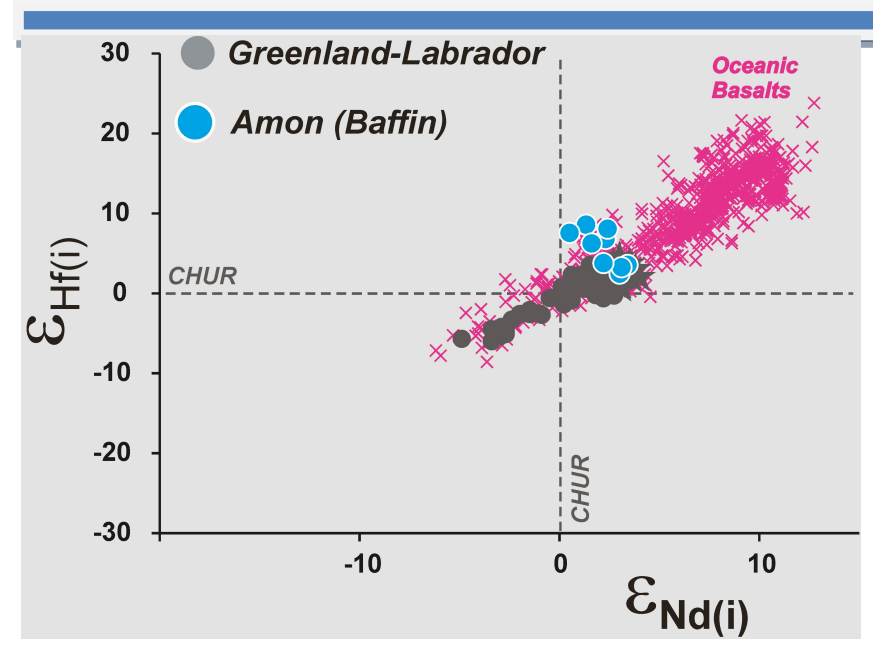

Figure 6: Initial Nd-Hf isotope compositions of the Amon kimberlites. Note the inverse correlation perpendicular to the mantle array as defined by oceanic basalts (database courtesy of A. Stracke). Neoproterozoic Greenland-Labrador kimberlites and aillikites are shown for comparison (Tappe et al., 2011, and references therein).

\section{ORIGIN OF THE AMON KIMBERLITES}

Although the temporal relationship between kimberlite and flood basalt magmatism in northern Baffin Island is not as clear-cut as observed in Siberia and India, the fact that large areas of the Canadian Arctic were impacted by the Franklin Large Igneous Event (723-712 Ma) only $30 \mathrm{Myr}$ prior to Amon kimberlite magmatic activity needs to be addressed in tectonomagmatic models for the region. Figure 1 shows the outline of the area in which basaltic remnants of the Franklin igneous events occur, together with a possible site of the magmatic centre (blue star), which is commonly inferred to represent the position of an impinging middle Neoproterozoic mantle plume below the NW Canadian Arctic (e.g., Ernst and Bleeker, 2010). In general, the production of cratonic flood basalt magmas is most plausibly explained in models where an impinging plume head is deflected from the thick plate interior to the craton margins (Thompson and Gibson, 1991; King and Anderson, 1995). Here, the buoyant mantle material can flow to shallower levels and subsequently undergo major melting and catastrophic venting (Foley, 2008). The most notable implication of this model for the Canadian Arctic is that the Franklin flood basalt magmas must have travelled laterally within the crust for several hundreds of kilometres to reach the areas well inside the Laurentia supercraton. Also, the plume material impinging directly on thick lithosphere must have spread out laterally, which restricts melting to a thin layer beneath the cratonic root (Foley, 2008). Although these "failed" plume heads are unable to penetrate through cratonic lithosphere, they produce small degree melts that invade the craton base. These low-volume melts do not have the heat capacity to directly move to Earth's surface. However, they transfer appreciable amounts of volatile elements, including carbon, into the cratonic lithosphere, where they depending on local redox conditions may precipitate either carbonates or diamonds as part of metasomatic assemblages (Foley, 2008).

Based on the fact that the lithosphere beneath northern Baffin Island was thick and diamond-bearing at $\sim 673 \mathrm{Ma}$, we conclude that impingement of the 723-712 Ma Franklin plume did not disrupt the cratonic mantle. We propose instead that plume-related, small degree melts metasomatized the base of the cratonic lithosphere, which included the precipitation of carbonate minerals. These readily fusible metasomatic components were remobilized some $30 \mathrm{Myr}$ later to give rise to the Amon kimberlite magmas. Although there is currently no compelling evidence for the tectonic trigger of Amon kimberlite magmatic activity, it seems reasonable to speculate that a change in the stress regime related to the late Neoproterozoic break-up of Laurentia (e.g., Iapetus Event in Fig.1) caused renewed thermal perturbation in the cratonic mantle.

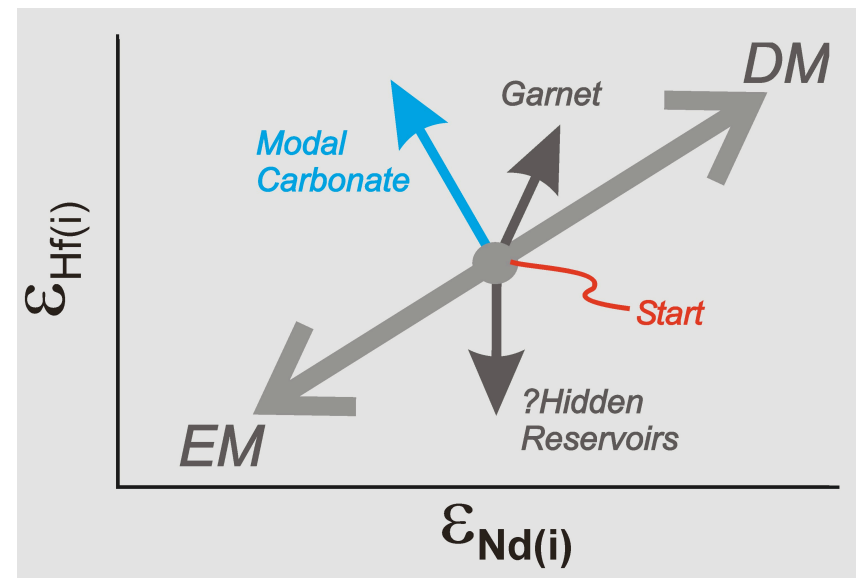

Figure 7: Schematic illustration of the theoretical Nd-Hf isotope effect in carbonate minerals, which were precipitated from sublithospheric melts within the cratonic mantle. Pronounced Hf isotope in-growth but retarded $\mathrm{Nd}$ isotope evolution of modal carbonates results in fast departure from the mantle array (tie line between Depleted and Enriched Mantle). Partly adopted from Bizimis et al. (2003).

Modelling of the somewhat unusual Nd-Hf isotope array defined by the Amon kimberlites supports the here proposed geological scenario. Mantle carbonate is one of the few materials that have the potential to significantly enrich Lu over Hf, while leaving the $\mathrm{Sm} / \mathrm{Nd}$ ratios relatively low (Bizimis et al., 2003). Such carbonates can therefore produce highly radiogenic $\mathrm{Hf}$ isotope compositions during extremely short time-scales and, importantly, decouple the Lu-Hf and Sm-Nd isotope systems (Fig.7). Our calculation suggests that mantle carbonates may experience Hf isotopic in-growth on the order of 30 epsilon units after only 10 Myr, while the $\mathrm{Nd}$ isotopic in-growth is much slower. Although the Hf concentrations of such mantle carbonates 


\section{$10^{\text {th }}$ International Kimberlite Conference, Bangalore - 2012}

are very low, it is their extreme isotopic composition that can leave a strong imprint on resulting carbonate-rich magmas, as we suggest for the Amon kimberlites. However, as $\mathrm{Nd}-\mathrm{Hf}$ isotope trends perpendicular to the terrestrial array are only rarely found in $\mathrm{CO}_{2}$-rich mantle-derived magma types, it follows that solid carbonates as part of metasomatic assemblages do not appear to play a significant role in their generation. Alternatively, and our favoured explanation, mantle carbonates have a rather restricted life expectancy within the cratonic lithosphere (Tappe et al., 2008), that is, they melt out too quickly to produce isotopic anomalies. Hence, the formation of kimberlite magmas in northern Baffin Island during the Neoproterozoic may represent a "sluggish" response to plume-craton interaction, which we may observe in other LIPs worldwide nearer to real-time (cf., Rao and Lehmann, 2011).

\section{REFERENCES}

Bizimis, M., Salters, V.J.M., Dawson, J.B., 2003. The brevity of carbonatite sources in the mantle: evidence from $\mathrm{Hf}$ isotopes. Contributions to Mineralogy and Petrology 145, 281-300.

Blichert-Toft, J., Albarede, F., 1997. The Lu-Hf isotope geochemistry of chondrites and the evolution of the mantle-crust system. Earth and Planetary Science Letters 148, 243-258.

Boctor, N.Z., Boyd, F.R., 1981. Oxide minerals in a layered kimberlitecarbonate sill from Benfontein, South Africa. Contributions to Mineralogy and Petrology 76, 253-259.

Carlson, R.W., Czamanske, G., Fedorenko, V., Ilupin, I., 2006. A comparison of Siberian meimechites and kimberlites: implications for the source of high-Mg alkalic magmas and flood basalts. Geochemistry, Geophysics, Geosystems 7, Q11014.

Denyszyn, S.W., Halls, H.C., Davis, D.W., Evans, D.A.D., 2009. Paleomagnetism and U-Pb geochronology of Franklin dykes in High Arctic Canada and Greenland: a revised age and paleomagnetic pole constraining block rotations in the Nares Strait region. Can. J. Earth Sci. 46, 689-705.

Ernst, R., Bleeker, W., 2010. Large igneous provinces (LIPs), giant dyke swarms, and mantle plumes: significance for breakup events within Canada and adjacent regions from $2.5 \mathrm{Ga}$ to the Present. Can. J. Earth Sci. 47, 695-739.

Foley, S.F., 2008. Rejuvenation and erosion of the cratonic lithosphere. Nat. Geosci. 1, 503-510.

Hoffman, P.F., 1988. United plates of America, the birth of a craton: early Proterozoic assembly and growth of Laurentia. Annu. Rev. Earth Planet. Sci. 16, 543-603.

King, S.D., Anderson, D.L., 1995. An alternative mechanism of flood basalt formation. Earth and Planetary Science Letters 136, 269-279.

Kjarsgaard, B.A., Pearson, D.G., Tappe, S., Nowell, G.M., Dowall, D., 2009. Geochemistry of hypabyssal kimberlites from Lac de Gras, Canada: comparisons to a global database and applications to the parent magma problem. Lithos 112, 236-248.

Le Roex, A.P., Bell, D.R., Davis, P., 2003. Petrogenesis of Group I kimberlites from Kimberley, South Africa: evidence from bulk-rock geochemistry. Journal of Petrology 44, 2261-2286.

Lehmann, B., Burgess, R., Frei, D., Belyatsky, B., Mainkar, D., Rao, N.V.C., Heaman, L.M., 2010. Diamondiferous kimberlites in central India synchronous with Deccan flood basalts. Earth and Planetary Science Letters 290, 142-149.

Mitchell, R.H., 1995. Kimberlites, orangeites, and related rocks. Plenum Press, New York.

Mitchell, R.H., Chakhmouradian, A.R., 1998. Instability of perovskite in a $\mathrm{CO}_{2}$ - rich environment: examples from carbonatite and kimberlite. Can. Mineral. 36, 939-952.
Nielsen, T.F.D., Jensen, S.M., Secher, K., Sand, K.K., 2009. Distribution of kimberlite and aillikite in the Diamond Province of southern West Greenland: a regional perspective based on groundmass mineral chemistry and bulk compositions. Lithos 112, 358-371.

Pehrsson, S.J., Buchan, K.L., 1999. Borden dykes of Baffin Island, Northwest Territories: a Franklin U-Pb baddeleyite age and a paleomagnetic reinterpretation. Can. J. Earth Sci. 36, 65-73.

Rao, N.V.C., Lehmann, B., 2011. Kimberlites, flood basalts and mantle plumes: new insights from the Deccan large igneous province. EarthSci. Rev. 107, 315-324.

Tappe, S., Foley, S.F., Kjarsgaard, B.A., Romer, R.L., Heaman, L.M., Stracke, A., Jenner, G.A., 2008. Between carbonatite and lamproite diamondiferous Torngat ultramafic lamprophyres formed by carbonate-fluxed melting of cratonic MARID-type metasomes. Geochimica et Cosmochimica Acta 72, 3258-3286.

Tappe, S., Steenfelt, A., Heaman, L.M., Simonetti, A., 2009. The newly discovered Jurassic Tikiusaaq carbonatite-aillikite occurrence, West Greenland, and some remarks on carbonatite-kimberlite relationships. Lithos 112, 385-399.

Tappe, S., Pearson, D.G., Nowell, G.M., Nielsen, T.F.D., Milstead, P., Muehlenbachs, K., 2011. A fresh isotopic look at Greenland kimberlites: cratonic mantle lithosphere imprint on deep source signal. Earth and Planetary Science Letters 305, 235-248.

Thompson, R.N., Gibson, S.A., 1991. Subcontinental mantle plumes, hotspots and pre-existing thinspots. Journal of the Geological Society of London 148, 973-977. 